\title{
Editorial
}

\section{In its darkest times, Haiti is still the world's hope, and a mirror of the Latino/a experience}

Latino Studies (2010) 8, 1-3. doi:10.1057/lst.2010.8

People, even in their darkest, or the deepest moment, they keep getting hope they will go up ... They don't want to die. They don't choose to die. They will resist ... Little hope ... they will continue to ... Zamni Lasante, Partners in Health ${ }^{1}$

Haiti. The world has been talking, and talking - and talking - about Haiti. But in spite of all the talking, ultimately, not much has been done. I write this editorial 3 weeks after the earthquake on 12 January 2010 destroyed the country - following the seven hurricanes that had already devastated its people's lives since 2008 .

Reports on Democracynow.org and other responsible news outlets point to the continued desperation of the hundreds of thousands around the country, many of whom have yet to receive any aid, 3 weeks after the January earthquake, which has now further ravaged Haiti and its people. As Amy Goodman reported on 2 February 2010, "survivors are still desperate to receive aid, with food, water and medical relief not reaching the areas it's needed most." To a large extent, this is because of the US emphasis on military security, and even suspended medical evacuations, delayed for 5 days, as a result of quibbles with Florida officials over who would foot the bill - all this to the detriment of people's lives. ${ }^{2}$

Indeed, despite the immediate and generous response from citizens from countries all over the world, including the United States, Yesica Fisch and Martha Mendoza noted, in their brief report published by the Associated Press over 2 weeks after the earthquake, that the Haitian government is receiving less than 1 cent for each dollar of aid:

Less than a penny of each dollar the US is spending on earthquake relief in Haiti is going in the form of cash to the Haitian government ... Each American dollar roughly breaks down like this: 42 cents for disaster assistance, 33 cents for US military aid, nine cents for food, nine cents to transport the food, five cents for paying Haitian survivors for recovery

1 BZ Worldwide. Haitian Hope. http://vimeo.com/ 5737494 (accessed 4 February 2010); This video documents the devastation in Haiti, during its last hurricane in the summer of 2008 - a reminder that the 12 January 2010 earthquake has occurred after repeated and recent devastating damages to the island, from the effects of climate change - or "climate instability" as noted Indian environmentalist, Vandana Shiva, more accurately defined it at the December 2009

Copenhagen Climate Change meetings - cf. http://www 
.democracynow .org/2009/12/

14/indian environmentalist vandana_shiva_ it_is (accessed 4 February 2010).

2 Amy Goodman. Democracynow .org, 2 February 2010; http://www .democracynow .org/2010/2/ 2/haiti (accessed 4 February 2010).

3 Yesica Fisch and Martha Mendoza. Haiti govt gets 1 penny of US quake aid dollar. Associated Press, 27 January 2010, http://hosted .ap.org/dynamic/ stories/L/LT_ HAITI_US_AID? SITE $=$ TXCOL\& SECTION=HOME \&TEMPLATE $=$ DEFAULT (accessed 4 February 2010).

4 A similar case could be made for Brazilians in the efforts, just less than one cent to the Haitian government, and about half a cent to the Dominican Republic. ${ }^{3}$

Although the US media continues to tout this country's efforts in Haiti, largely to the exclusion of any mention of other countries, it is important to note that, in contrast to the immediate and substantial assistance to Haiti from other parts of the Americas, arrival of US aid efforts included a week-long delay, and only materialized after the visible and highly publicized deployment of US military security forces to the country. In this respect, perhaps the most egregious is the US media's lack of emphasis on the invaluable and immediate assistance of countries such as the Dominican Republic, and the total disregard for Brazil's impressive mobilization on behalf of Haiti - a country that, as the principal UN peacekeeping force in Haiti at the time, also lost many of its own citizens during the earthquake.

Like the history of Latino/as in the United States, the history of the Haitian people embodies the hopes and ongoing resistance of the hemisphere's populations to the inequities imposed by US domination throughout the Americas. Similar to the Latino/a experience, the ongoing invisibility of Haitians' contributions to the United States and to the world continues unabated. Haiti is, after all, the only country in the Americas that successfully defeated slavery certainly, among the world's most heinous perversities - to become the world's first independent Black republic. It also embodies Latin America's history of struggle and resistance against US intervention and the imposition of US-backed dictatorships and policies on that continent - most notably substantiated by the Monroe Doctrine (1823) and the ideology of Manifest Destiny that since the midnineteenth century have been used throughout the Americas to justify the multiple US invasions, nefarious dictatorships, and imposed economic models that have served only to distort the development and aspirations of the majority of the Latin American and Caribbean people. As a result, like the millions of people of Latin American descent now in the United States, the ongoing ideological and practical repercussions of the US imperial reach have long ensured the continued and largely forced displacement and migration of hundreds of thousands of Haitians from their homeland to the United States.

Moreover, as the birthplace of the modern ideology of race in the Americas, Haiti is inexorably tied to the historical roots of the inequities in the everyday lives of Latin Americans and of Latino/as in the United States. Considered and comprehended in these terms, it is imperative to ponder the "place" of Haiti in Latino/a studies. Haitians do not speak Spanish and, as a result, are often excluded from courses on Latino/as in the United States. In this respect, ironically, the invisibility of Haitians in Latino/a studies reproduces the invisibility of Latino/as' own experience in the study of the United States. ${ }^{4}$

Clearly, a growing number of Latino/as and Latino/a organizations across the country are increasingly aware of our close connection with Haiti's past and, 
certainly, its present. A case in point is the immediate mobilization of US Latino/as, in Orlando, in Rhode Island, in Oregon and all across the country, to raise relief support, to send supplies and aid, and gather in candlelight vigils for those who died in the earthquake; ${ }^{5}$ various Latino/a media outlets across the country immediately put fundraising for Haiti's earthquake victims at the top of their agenda. In Florida, where the discrepancy between the more favorable treatment afforded to Cuban refugees than to arriving Haitian immigrants has never been lost on anyone, Latino/as have been working with Haitians over the past few years, to build bridges between the two populations. Thus, Winnie Contave, described in the Washington Post as "a Haitian-American community leader and director of a Miami-based nonprofit that provides leadership training to immigrant workers," credits this important recent development to the ongoing efforts by activists to bring together Latinos and Haitians, noting that, "that spirit has been giving some fruit in this crisis." 6

In Chicago, Latino/a radio station hosts urged people to contribute to the aid effort; in Los Angeles, an event in support of the Haitian earthquake survivors declared that "La Raza Está Con Haiti." The Coalition for Immigrants Rights in Los Angeles (CHIRLA) "applaud[ed] the Obama Administration for halting the deportation of Haitian immigrants," recalling the recent devastations of hurricanes and hurricanes in Central American nations. ${ }^{7}$ Sabado Gigante aired a 5-hour uninterrupted telethon program, Unidos Por Haiti, to raise funds for the relief effort, again pointing to Latino/a solidarity with the Haitian people explained by Juanes, one of the many participating Latino/a artists, in the following terms: "I view Haiti as part of our community ... It's part of our region. Maybe that's the small bright spot that comes out of this, that that is how people are seeing the country more."7

As scholars, I believe that it is time to further and openly incorporate Haitian history and contemporary experience into the discourse and debate on Latino/as in the United States. Consciousness about Haiti's history and its ongoing centrality to the experience of the Americas will undoubtedly enhance our appreciation of the import of race both within and among Latino/a populations, and in the US context. It will also contribute in important ways to the further development of our understanding of some of the roots of Latino/as' own struggles and experiences in the United States. Herein, precisely, lies the relevance of Haiti for Latino/a Studies.

Saludos!
United States, who also do not speak Spanish, and are often excluded from Latino Studies courses.

5 http://blogs

.orlandosentinel .com/news hispanicaffairs/ 2010/01/

central-floridalatinos-helpinghaiti.html; http:// www.projo.com/ news/content/ RI_AID_TO_

HAITI_01-26-10_

T4H83CE_v11

.3a6665d.html;

http://www

.mercycorps .org/fundraising/ amigos-

harrisonparksun (accessed 5

February 2010).

6 Laura Wides Muñoz. Hispanic media outreach for Haiti unprecedented. Associated Press, 1 February 2010, http://www .washingtonpost .com/wp-dyn/ content/article/ 2010/02/01/

AR20100

20100241

.html (accessed 4 February 2010).

$7 \mathrm{http}: / / \mathrm{www}$ .chirla.org/ en/node/798; 14 January 2010 (accessed 5 February 2010).

John Jay College of Criminal Justice, City University of New York, New York E-mail: soboler@jjay.cuny.edu 